\title{
Diagoras, Bellerophon and the Siege of Olympus
}

Few of the figures who populated the classical Athenian intellectual landscape are so simultaneously alluring and mysterious as Diagoras of Melos. For later generations, he was the atheist par excellence, whose exploits included burning a wooden statue of Heracles, and rebuffing conventional pieties with witticisms. Aristophanes linked him with sophists who challenged conventional ideas about the gods. He was almost certainly exiled, probably in around $416 \mathrm{BCE}$, for religious transgressions involving the divulging and mockery of the Mysteries. ${ }^{1}$ Little, however, is known of the reason for his reputation. Was it won simply for his profanation? Or did his writings also contain arguments against the existence of gods, such as we know to have been circulating in the 420 s and 410 s? ${ }^{2}$

The tendency in the last fifty years has been to answer this last question in the negative. ${ }^{3}$ Winiarczyk, the most influential sceptic, argues that the atheistic book must have been a philosophical or sophistic work of the fourth century that was subsequently misattributed to him. He bases this view on a claim that atheistic argumentation (as opposed to involvement in the profanation of the Mysteries) is not attested until late and reflects the Hellenistic development of a legend. ${ }^{4}$ This cannot quite be right: the association with atheism clearly goes back at the very least to the fourth century, since Epicurus in On Nature grouped him among

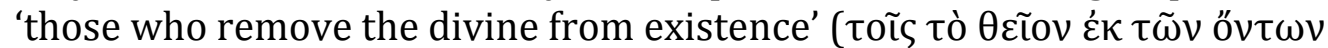

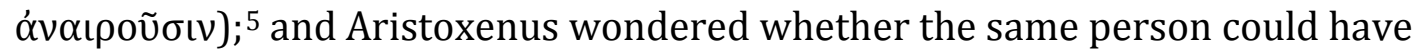
written pious verse and atheistic prose. ${ }^{6}$ In fact, references in Aristophanes (discussed below: see especially n. 26) seem to suggest that he was already in the late 420 s associated with unconventional philosophical beliefs concerning the gods.

Sceptics have also emphasised that the two surviving verbatim fragments of

\footnotetext{
1 Statue: T6A, 11, 27-33 in Winiarczyk 1981. Rebuffing pieties: T 34-35B. Aristophanes: see below. His biography is discussed by Jacoby 1959 (who puts the date of the exile earlier, in ca. $430 \mathrm{BCE}$ - a view that has not won support), Woodbury 1965 and Winiarczyk 1979, 1980. Janko 2001 (cf. 2002-3) speculates that Diagoras was the author of the Derveni papyrus, an ingenious suggestion that has however not won universal support: see e.g. Betegh 2004: 373-80. Professor Winiarczyk tells me (personal communication) that he is soon to publish a full monograph on Diagoras.

2 For recent discussion of the wider intellectual context see Whitmarsh 2015: 8797.

${ }^{3}$ See esp. Woodbury 1965 and Winiarczyk 1980.

4 Winiarczyk 1980: 71-3.

5 Philodemus On Piety 19.519-33 (see Obbink 1996: 353) = Diagoras T 39 Winiarczyk.

${ }^{6}$ P.Herc. 1428 col. 11 (published after Wehrli's edition): see Henrichs 1974: 21-2 = Diagoras $\mathrm{T} 69$ Winiarczyk.
} 
Diagoras, both from his poetical works, suggest a conventional piety. ${ }^{7}$ As a poet, certainly, he seems to have played by the theological rules; but the argument that an atheist could not have written religious poetry is a rather naïve one (even if it has ancient pedigree). ${ }^{8}$ Occasional poetry does not require the author's philosophical commitment to every single sentiment that it expresses, and in any case Diagoras' supposed poetic 'theism' in fact consists of little more than a conventional notion of the limitations and frailties of mortals. There is, moreover, nothing to stop writers from changing their minds in the course of their lifetimes (as indeed the biographical testimony suggests Diagoras did).

The ancient sources are never more persistent in their ascription of atheism than they are to Diagoras, and we should not dismiss these lightly. ${ }^{9}$ At the centre of

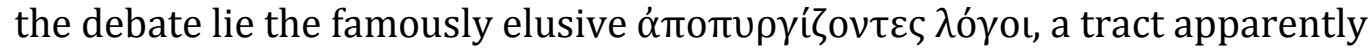
written in prose, ${ }^{10}$ and said by the Suda to detail 'his withdrawal and retreat from his belief in the gods'. ${ }^{11}$ Should we trust the attribution of this text to him, ${ }^{12}$ and if so what was in it? ${ }^{13}$ In this brief note I offer a maximalist reading of the evidence which, if necessarily hypothetical, will suggest that scepticism is not the only option.

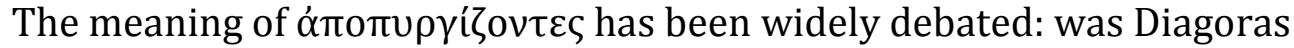
promising to throw the gods from towers, wall them in, or knock them down like towers? Or did he mean to fortify his own position? Or - as one scholar has

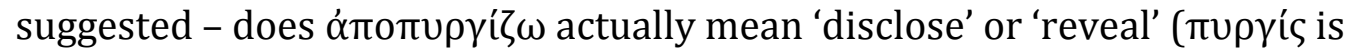
attested, albeit weakly, in the sense of 'coffer')? ${ }^{14} \pi u \rho \gamma$ ' $\zeta \varepsilon v v$ is otherwise

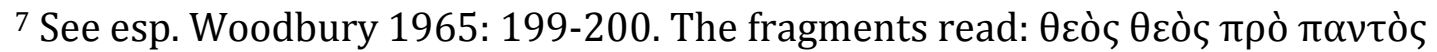

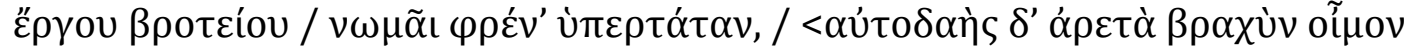
है $\pi \varepsilon เ v>$ ('The god, the god wields the highest wisdom on behalf of all human action; human virtue when self-taught proceeds along a short path'); $\kappa \alpha \tau \grave{\alpha}$

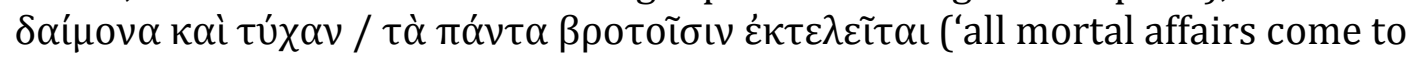
pass thanks to the deity and fortune'): F 1-2 Winiarczyk.

8 See Aristoxenus, as quoted by Philodemus (n. 6).

9 Winiarczyk 1984: 164-6 gives 33 references to his 'atheism' or impiety, more than for anyone else in antiquity.

${ }^{10}$ Hordern 2001 however argues that his atheism may have been expressed poetically.

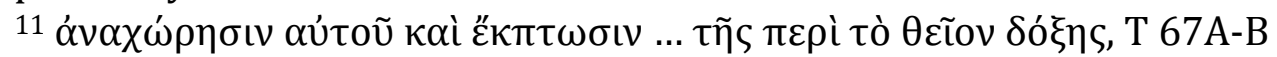

Winiarczyk (= Suda $\Delta$ 523). Tatian (Or. ad gr. 27 = T68 Winiarczyk) mentions

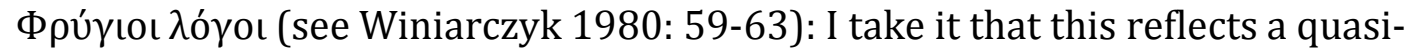

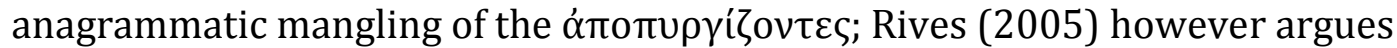
that this was a real text that was subsequently misattributed to Diagoras.

12 Already in the fourth century Aristoxenus (apud Philodemus: see n. 6) had cast doubt on the authenticity of atheistic views attributed to him, apparently on the grounds of their incompatibility with his theistic poetry.

${ }^{13}$ Hordern 2001: 34 n. 6 suggests, 'for what it is worth', a possible emendation to

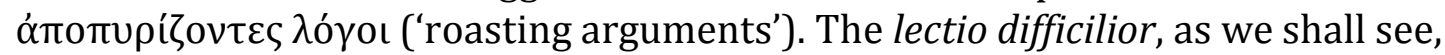
is explicable and preferable.

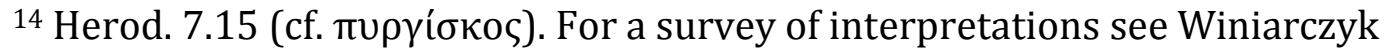
1980: 54-8 (who cites the unpublished suggestion 'disclose'). 
unattested, prefixed or not, in ancient Greek. The uncompounded meaning should be 'fortify with a tower', 15 just as $\tau \varepsilon x \chi$ ' $\zeta \varepsilon ı v$ means 'fortify with a wall'. The

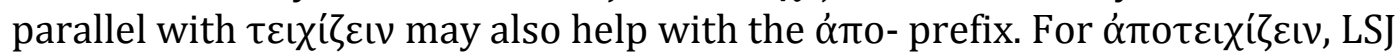
s.v. has two broad categories of meaning: (i) separate $\mathrm{x}$ by building a wall; ${ }^{16}$ (ii) remove a wall from $\mathrm{x} .{ }^{17}$ Diagoras' logoi were probably intended either to effect some kind of partition by building a tower, ${ }^{18}$ or to demolish one. Given that the argument appears to have been aggressive towards established religion, the second definition is more likely; and indeed this interpretation may be

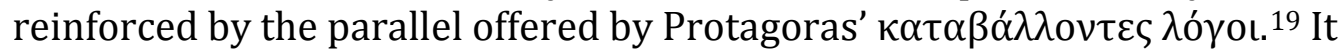
seems prima facie plausible, then, that Diagoras' arguments were intended, metaphorically, to destroy city fortifications by a kind of intellectual siege. ${ }^{20}$

Further support for this thesis may come in the form of a well-known fragment of Euripides' Bellerophon (performed perhaps in 426 BCE). ${ }^{21}$ After offering an argument (to which we shall return) to the effect that the absence in the world of any systematic rewarding of the virtuous or punishment of the wicked demonstrates the non-existence of gods (i.e. the 'problem of evil'), the passage

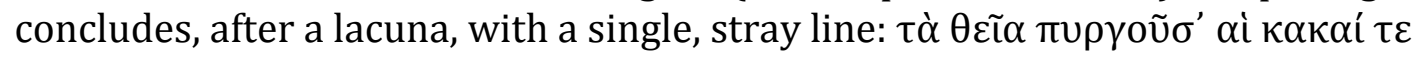
$\sigma u \mu \varphi о \rho \alpha$ i. $^{22}$ What filled the lacuna, and hence completed the meaning of the sentence, is a long-standing puzzle. It seems likely (as Riedweg notes) that the general sense is ' $x$ and terrible disasters fortify religion'; ${ }^{23}$ i.e. that belief in the gods is a human construction analogous with a city, and that it is the general misery of human existence that buttresses it. This would complement views found elsewhere in late fifth-century thought, most notably in the Sisyphus fragment, where the ingenious human creator of religious belief exploits mortal fears and vulnerabilities. ${ }^{24}$ What is significant for the present discussion,

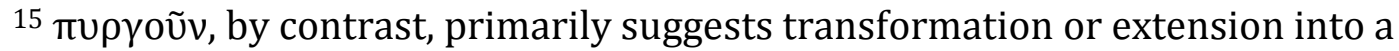
tower (rather than equipping with one).

16 As at Ar. Av. 1576, discussed at the end of this note.

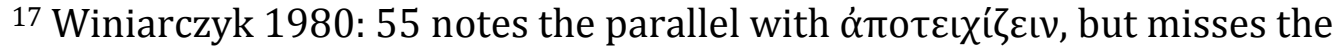
second meaning.

18 Thus the Brill Dictionary of Ancient Greek offers 'to defend from turrets' wisely adding 'sens. $d u b$. '

${ }^{19}$ Fr. 1 D-K. For $\kappa \alpha \tau \alpha \beta \alpha ́ \lambda \lambda \varepsilon \varepsilon \nu=$ 'demolish' a fortification see Thuc. 7.24.1. Clearly, however, the verb can suggest a range of compatible metaphors (one referee suggests a wrestling 'throw').

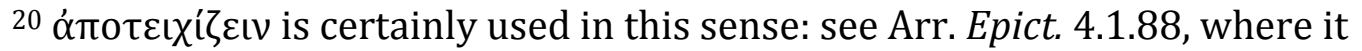
indicates an attack on the acropolis of a tyrant.

21 It probably preceded Aristophanes' Acharnians (cf. the apparent allusion at 426-9), performed in 425; but it must have still been fresh in the audience's mind in 421, when Peace was shown.

22 TGrF 5.1 F286. Collard, Cropp and Lee 1995: 104 note the possibility that this stray line 'may be a separate fragment'. Ps-Justin, however, our source for the passage, certainly quotes it as if it were a single unit (De Monarch. 108c-e).

${ }_{23}$ Riedweg 1990: 45-6. He suggests that the sentence began, in the previous line,

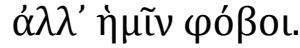

24 'Critias' TGrF 143 F19.27-40.
} 


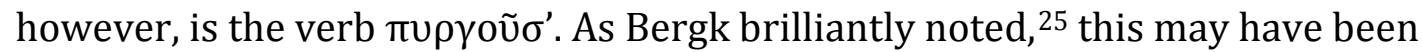

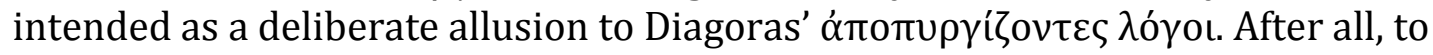
observe that religion is a fortification (as the speaker does here) is in effect to locate it within a discourse of oppugnability. ${ }^{26}$

The atheistic argument in the Bellerophon fragment may also be rooted in Diagoras' thought. Euripides was of course fond of borrowing from contemporary philosophical ideas, and the phrasing strongly suggests an origin in reasoned prose. ${ }^{27}$ According to the Suda (paraphrasing a 6th-century De viris illustribus), Diagoras turned to atheism because of an event in his own life. Another poet, who had plagiarised one of his paeans, after swearing his innocence delivered a prize-winning performance of Diagoras' work. As a result

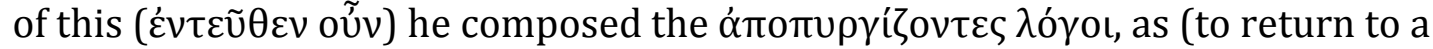
phrase that we have already seen) a 'withdrawal and retreat from his belief in the gods'. ${ }^{28}$ The point of this anecdote is that the rival was not punished by the gods for his perjury, a negligence that Diagoras took as evidence for their inefficacy. If the anecdote goes back to Diagoras' own writings - which is unprovable, given the current state of our evidence, but hardly impossible - then it suggests that the inability of the gods to punish wrongdoers was an important component of his argument against their existence. This reasoning also underlies the well-known anecdote about Diagoras in the seastorm: when fellow sailors asserted that the gods were targeting their ship in revenge for his atheistic claims, Diagoras asked why in that case the other ships in the area were also in difficulty. ${ }^{29}$ Again the implication is that the gods have no ability to punish wrongdoers and reward the virtuous. This, crucially, is also the central argument of the atheistic speaker in Euripides' Bellerophon (TGrF 5.1 F286.5-12): tyrants are responsible for mass murder, confiscation, oath-breaking (a point of direct connection to the Diagoras anecdote) and city-sacking, yet they prosper more

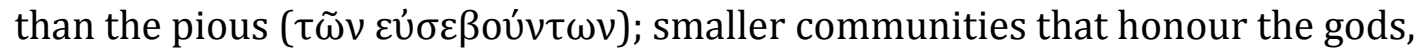
meanwhile, are dominated by more impious ( $\delta v \sigma \sigma \varepsilon \beta \varepsilon \sigma \tau \varepsilon \dot{\varepsilon} \rho \nu)$ ones through force of arms. Pious behaviour, in other words, is not rewarded, nor is impiety

25 Bergk 1884: 473. I am not convinced by Dixon 2014 that these lines are spoken by Stheneboea rather than Bellerophon. If, as Jacoby argued (1959: 30),

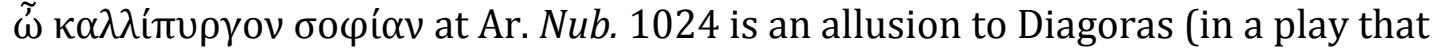
contains another almost certain reference: see following $\mathrm{n}$.), then this further suggests that our author was in the 420 s directly associated in the public's mind with 'towers'.

26 That Diagoras was known for 'atheism' already in the 420s is clear from Ar. Nub. 830 ('Socrates the Melian': explained by $\Sigma$, surely rightly, as an allusion to Diagoras), a passage thought to have survived from the original version performed in 423.

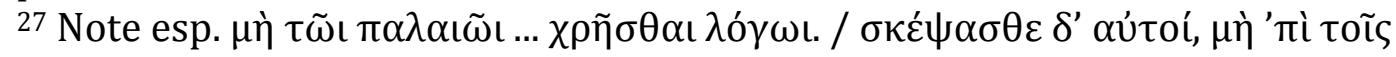

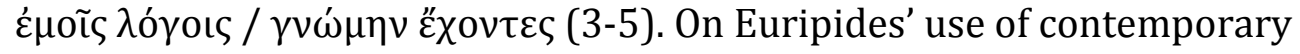
philosophical ideas see Egli 2003, who discusses our fragment at 146-8 (suggesting the influence of Prodicus or Democritus). ${ }^{28}$ Suda s.v. $\Delta$ เ $\alpha \gamma$ ó $\rho \alpha \varsigma=\mathrm{T} 9 \mathrm{~A}$ Winiarczyk ( $c f$. T 9B; different version, with the same moral, at T 26).

29 T 34-35B Winiarczyk. 
punished.

Euripides' play, as we can tell from Aristophanes' parody in Peace (421 BCE), deployed the mékhanē to swing Bellerophon up towards Olympus (i.e. the roof of the skennē) on the back of a mechanical Pegasus; he then tumbled down to earth, and became lame as a result of the fall. ${ }^{30}$ It seems likely that his attempted journey to Olympus was motivated by his atheistic reasoning: either he wanted to prove the non-existence of the gods or he wished to confront them about their unjust stewardship of the cosmos (as Trygaeus seeks to do in Peace). The Bellerophon myth thus seems to have furnished Euripides with the opportunity to explore cutting-edge intellectual reasoning about the gods within the 'safe space' of a narrative that reasserted their superiority over mortals: for, as Lefkowitz has noted, Euripidean characters who explore experimental theologies tend to get their comeuppance. ${ }^{31}$

This Bellerophon-Diagoras connection may also suggest that Diagoras styled

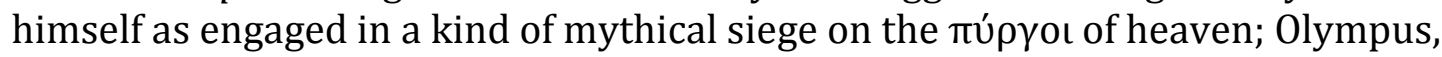
that is, was imagined as a city that stood metonymically for religion as a whole. (Diagoras will not, for sure, have cast himself as the doomed Bellerophon: that must have been Euripides' contribution.) Aristophanes' Birds of 414 may support this thesis. This extraordinary play, which is about an attempt by two Athenians to displace the gods and found a new city in the sky, is heavily Diagorean at the thematic level (at least on our reconstruction of the Melian's ideas); and this connection is reinforced by a series of three references to our writer. ${ }^{32}$ Most prominent is the famous allusion (1072-8) to a decree, inscribed on a bronze stele, offering to reward anyone who killed Diagoras, since he had profaned the Mysteries and (at some point in the mid-410s) escaped to Pellene. ${ }^{33}$ Passing over the brief allusion at $1420-1,{ }^{34}$ we come to the 'Melian famine' with which the gods are threatened (186; i.e. by withholding sacrifice), which clearly points to Diagoras (as well as to the Athenian sack of Melos in 416). In the wider passage,

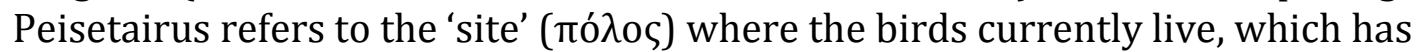

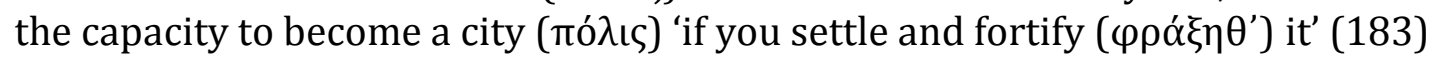
- in that case, the birds will rule over humans 'and destroy the gods with a

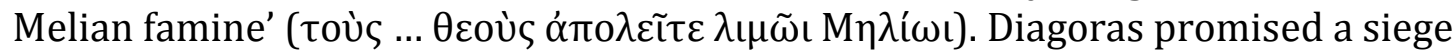
of Olympus using arguments as machinery; the birds will attempt to achieve the same end, but by creating and fortifying their own aerial city, and starving the gods out. Whereas Diagoras had promised 'arguments that knocked down

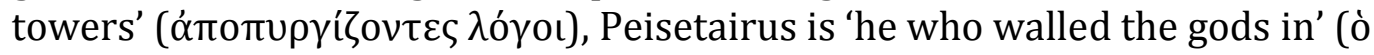

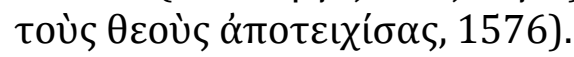

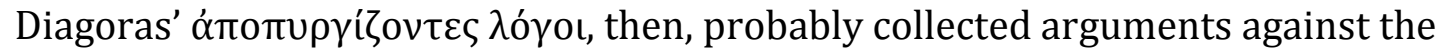
existence of gods, arguments based in the observable absence of theodicy in the

\footnotetext{
${ }^{30}$ Ar. Pax 135-6, 146-8.

31 Lefkowitz 1989.

32 Romer 1994.

33 This stele seems to have been historical, or at least treated as such by Craterus of Macedon (FGrH 342 F16).

34 Romer 1994: 355-6.
} 
world. These were probably nested within a narrative or metaphorical frame portraying the author (or his surrogate) as a $\theta \varepsilon o \mu \alpha$ ó $\chi$, laying siege to the heavens; the influence of this can be seen in the dramatic literature of the $420 \mathrm{~s}$ and 410s, which when speaking of atheism recurs to the idea of aerial flight and armed combat against the citadel of Olympus. ${ }^{35}$

Tim Whitmarsh

University of Cambridge

\section{References}

Bergk, T. 1884. Griechische Literaturgeschichte Bd. 3, ed. G. Hinrichs. Berlin. Betegh, G. 2004. The Derveni Papyrus: Cosmology, Theology and Interpretation. Cambridge.

Campbell, D. 1992. Greek Lyric IV: Bacchylides, Corinna, and Others. With an English Translation. Cambridge, MA.

Collard, C., Cropp, M. J. and Lee, K. H. 1995. Euripides, Selected Fragmentary Plays. Volume 1. Warminster.

Dixon, D. W. 2014. 'Reconsidering Euripides' Bellerophon'. CQ 64: 493-506. Egli, F. 2003. Euripides im Kontext zeitgenössischer intellektueller Strömungen: Analyse der Funktion philosophischer Themen in den Tragödien und Fragmenten. Munich and Leipzig.

Henrichs, A. 1974. 'Die Kritik der stoischen Theologie im P. Hercul. 1428'. Cronache Ercolanesi 4: 5-32.

Hordern, J. 2001. 'Philodemus and the Poems of Diagoras'. ZPE 136: 33-8. Jacoby, F. 1959. Diagoras ò ö $\theta \varepsilon o \varsigma$. Berlin.

Janko, R. 2001. 'The Derveni Papyrus (Diagoras of Melos, Apopyrgizontes Logoi?): a New Translation'. CPh 94: 1-32.

Janko, R. 2002-3. 'God, Science, and Socrates'. BICS 46: 1-18.

Lefkowitz, M. R. 1989. "Impiety” and "Atheism” in Euripides' Dramas'. CQ 39: 7082. Repr. in J. Mossman (ed.), Euripides. Oxford, 2003: 102-21.

Obbink, D. 1996. Philodemus On Piety. Part 1. Critical Text and Commentary. Oxford.

Riedweg, C. 1990. 'The "Atheistic" Fragment from Euripides' Bellerophontes (286 $\left.\mathrm{N}^{2}\right)^{\prime}$. ICS 15: 39-53.

Rives, J. 2005. 'Phrygian Tales'. GRBS 45: 223-44.

Romer, F. E. 1994. 'Atheism, Impiety and the Limos Melios in Aristophanes' Birds'. AJP 115: 351-65.

Whitmarsh, T. 2015. Battling the Gods: Atheism in the Ancient World. New York. Winiarczyk, M. 1979. 'Diagoras von Melos: Wahrheit und Legende'. Eos 67: 191213.

Winiarczyk, M. 1980. 'Diagoras von Melos: Wahrheit und Legende (Fortsetzung)'. Eos 68: 51-75.

Winiarczyk, M. 1981. Diagorae Melii et Theodori Cyrenaei Reliquiae. Leipzig. Woodbury, L. 1965. 'The Date and Atheism of Diagoras of Melos'. Phoenix 19: 178-211.

35 I am grateful to $J H S^{\prime}$ anonymous referees, and to Prof Douglas Cairns, for improvements to this note. 